\title{
Simultaneous Production of Bioemulsifier and Exopolysaccharides by Thermophilic Brevibacillus Borstelensis Using Response Surface Model, Genetic Algorithm and NSGA
}

Research

Keywords:

Posted Date: December 30th, 2020

DOI: https://doi.org/10.21203/rs.3.rs-132812/v2

License: (1) This work is licensed under a Creative Commons Attribution 4.0 International License. Read Full License 


\section{Abstract}

The authors have requested that this preprint be withdrawn due to erroneous posting.

\section{Full Text}

The authors have withdrawn this preprint from Research Square. 